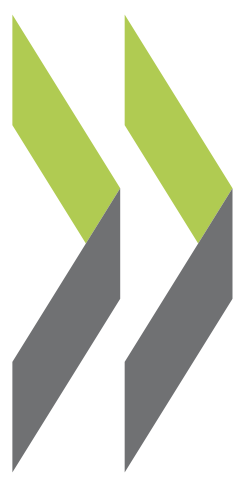

OECD Economics Department Working Papers No. 1166

The Effect of the Global Financial Crisis on OECD Potential Output

Patrice Ollivaud, David Turner 
Organisation de Coopération et de Développement Économiques

Organisation for Economic Co-operation and Development

25-Sep-2014

ECONOMICS DEPARTMENT

English - Or. English

THE EFFECT OF THE GLOBAL FINANCIAL CRISIS ON OECD POTENTIAL OUTPUT

ECONOMICS DEPARTMENT WORKING PAPERS No. 1166

By Patrice Ollivaud and David Turner

OECD Working Papers should not be reported as representing the official views of the OECD or of its member countries. The opinions expressed and arguments employed are those of the author(s).

Authorised for publication by Jean-Luc Schneider, Deputy Director, Policy Studies Branch, Economics Department.

All Economics Department Working Papers are available through OECD's internet website at www.oecd.org/eco/workingpapers

JT03362513

Complete document available on OLIS in its original format

This document and any map included herein are without prejudice to the status of or sovereignty over any territory, to the delimitation of international frontiers and boundaries and to the name of any territory, city or area. 
OECD Working Papers should not be reported as representing the official views of the OECD or of its member countries. The opinions expressed and arguments employed are those of the author(s).

Working Papers describe preliminary results or research in progress by the author(s) and are published to stimulate discussion on a broad range of issues on which the OECD works.

Comments on Working Papers are welcomed, and may be sent to OECD Economics Department, 2 rue André-Pascal, 75775 Paris Cedex 16, France, or by e-mail to eco.contact@oecd.org

This document and any map included herein are without prejudice to the status of or sovereignty over any territory, to the delimitation of international frontiers and boundaries and to the name of any territory, city or area.

The statistical data for Israel are supplied by and under the responsibility of the relevant Israeli authorities. The use of such data by the OECD is without prejudice to the status of the Golan Heights, East Jerusalem and Israeli settlements in the West Bank under the terms of international law.

\section{(c) OECD (2014)}

You can copy, download or print OECD content for your own use, and you can include excerpts from OECD publications, databases and multimedia products in your own documents, presentations, blogs, websites and teaching materials, provided that suitable acknowledgment of OECD as source and copyright owner is given. All requests for commercial use and translation rights should be submitted to rights@oecd.org 
ECO/WKP(2014)62

\section{ABSTRACT/RÉSUMÉ}

\section{The Effect of the Global Financial Crisis on OECD Potential Output}

This paper estimates potential output losses from the global financial crisis by comparing recent OECD published projections with a counter-factual assuming a continuation of pre-crisis productivity trends and a trend employment rate which is sensitive to demographic trends. Among the 19 OECD countries which experienced a banking crisis over the period 2007-11, the median loss in potential output in 2014 is estimated to be 33/4 per cent, compared to 23/4 per cent among all OECD countries. The crisis hit does, however, vary widely across countries, being more than $10 \%$ for several smaller European, mainly euro area, countries. The largest adverse effects come from lower trend productivity, which is a combination of both lower total factor productivity and lower capital per worker. Despite large increases in structural unemployment in some countries, the contribution of lower potential employment to the crisis hit is limited because the adverse effect on labour force participation is generally much less than might have been expected on the basis of previous severe downturns. This may partly reflect pension reforms and a tightening up of early retirement pathways. Pre-crisis conditions relating to over-heating and financial excesses, including high inflation, high investment, large current account deficits, low real interest rates, high total economy indebtedness and more rapid growth in capital-per-worker are all correlated with larger post-crisis potential output losses. This suggests that underlying the potential output losses was a substantial misallocation of resources, especially of capital, in the pre-crisis boom period. On the other hand, more competition-friendly product market regulation is associated with smaller crisis-related losses of potential output, suggesting it facilitates a reallocation of resources across firms and sectors in the aftermath of an adverse shock and so helps to mitigate its consequences.

Keywords: Banking crisis, financial crisis, global financial crisis, potential output. JEL classification: E32; E44.

\section{Les conséquences de la crise financière mondiale sur la production potentielle de l'OCDE}

Cette étude propose une estimation des pertes de production potentielle liées à la crise financière mondiale en comparant les projections de l'OCDE publiées récemment avec une situation hypothétique où les tendances de la productivité observées avant la crise sont maintenues et où le taux d'emploi tendanciel dépend des tendances démographiques. Parmi les 19 pays de l’OCDE qui ont connu une crise bancaire durant la période 2007-2011, l'estimation de la perte médiane de potentiel de production atteint 3,75 pour cent en 2014, à comparer avec 2,75 pour cent pour tous les pays de l'OCDE. L'impact de la crise, cependant, varie beaucoup selon les pays, et dépasse $10 \%$ pour plusieurs petits pays européens, notamment dans la zone euro. L'effet négatif vient principalement d'une plus faible productivité tendancielle, combinaison d'une plus faible productivité totale des facteurs et d'un capital productif par travailleur inférieur. En dépit d’une augmentation conséquente du taux de chômage structurel dans plusieurs pays, la contribution de l'emploi potentiel à l'impact total de la crise est faible, notamment parce que l'effet négatif sur les taux d’activité a été en général beaucoup moins important que ce qui était attendu au vu des récessions précédentes. Cela traduit en partie les réformes passées sur les retraites et un resserrement des conditions de départ anticipé à la retraite. La surchauffe économique et les excès financiers, y compris une forte inflation, un investissement élevé, un déficit important de balance courante, un taux d’intérêt réel bas, un endettement important de l'ensemble de l'économie et enfin une croissance plus rapide du capital par travailleur, sont des conditions préalables corrélées à la perte de potentiel de production. Cela suggère que la source de ces pertes de potentiel réside dans une mauvaise répartition des ressources, et notamment de capital, dans la période de boom précédant la crise. Par ailleurs, une réglementation plus souple des marchés des produits est associée à des pertes moins importantes de potentiel de production liées à la crise, suggérant ainsi qu'elles améliorent la redistribution des ressources entre les firmes et les secteurs quand survient un choc négatif, et par conséquent, participent à limiter ses conséquences.

Codes JEL : E32; E44.

Mots Clés : Crise bancaire, crise financière, crise financière mondiale, potentiel de production, production potentielle 


\section{TABLE OF CONTENTS}

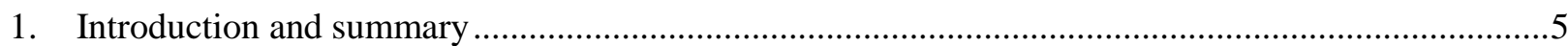

2. A selective review of recent studies of the medium-term output losses following financial crises .....7

3. Analysing the effect of the current crisis on potential output.......................................................10

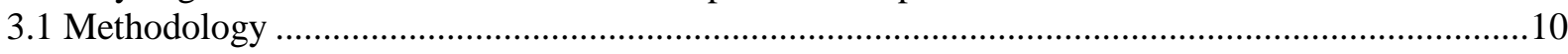

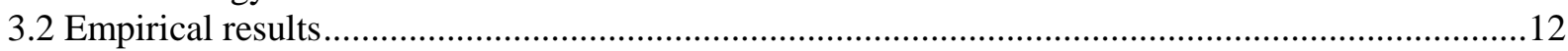

4. Relating the crisis hit to potential output with pre-crisis conditions …........................................17

Appendix 1. The OECD Methodology for Generating Potential Output .......................................................20

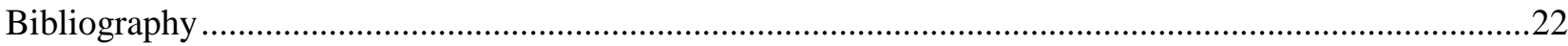

\section{Tables}

Table 1. Estimated effects of the crisis on the potential output of OECD countries in 2014 ...................13

Table 2. The relationship between the loss in potential output and pre-crisis conditions..........................19

\section{Figures}

Figure 1. OECD GDP per capita compared to various pre-crisis trends...................................................9

Figure 2. Estimated effects of the crisis on the potential output of OECD countries ...............................12

Figure 3. Contributions to the crisis hit on potential output for individual OECD countries ....................14

Figure 4. Estimated effects of the crisis on the components of potential output ......................................15

Figure 5. The crisis hit to participation and the change in net migration..................................................16 
ECO/WKP(2014)62

\title{
THE EFFECT OF THE GLOBAL FINANCIAL CRISIS ON OECD POTENTIAL OUTPUT
}

\author{
By Patrice Ollivaud and David Turner ${ }^{1}$
}

\section{Introduction and summary}

1. The global financial crisis has been extremely costly in terms of lost output and jobs. A crucial judgement for macroeconomic policy is how much of this loss will persist once cyclical recovery is complete. Specifically, what level of loss in medium-term output will remain relative to the trajectory that might have been expected in the absence of the crisis. ${ }^{2}$ The extent of such losses is a particularly important consideration for fiscal policy given the large increase in government deficits and debt experienced by many OECD countries; the greater the loss, the less that fiscal balances will improve with any recovery and so the greater the need for discretionary action to correct remaining fiscal imbalances. The extent of the loss in capacity to produce output without generating unsustainable macroeconomic imbalances is also relevant for monetary policy; the greater the loss, the sooner any recovery will run into capacity constraints and so the sooner the need to normalise policy rates and end unconventional monetary easing. An understanding of which countries have been most severely impacted by the crisis is also of relevance to policy, as it may cast light on which pre-crisis conditions and policies make economies vulnerable to such shocks and so suggest ways of improving resilience in the future.

2. Evaluating the effect of the crisis on medium-term output prospects is inherently problematic, given the impossibility of knowing what the counter-factual is and because of the difficulties of disentangling the effect of the crisis from other effects, including policy changes. Moreover, even nearly six years after the crisis, with many economies judged to be operating well below capacity, any assessment can only be preliminary. The approach in the current paper is based on OECD published estimates of potential output, which is that estimated trend level of output which can be sustained without generating inflationary pressures. Losses related to the crisis are evaluated relative to a counter-factual assuming a continuation of pre-crisis productivity trends, but with alternative assumptions regarding the different components of the trend employment rate.

3. The main findings of the paper are as follows:

1. The authors are economist and Head of Division, respectively, from the OECD Macroeconomic Analysis Division of the Economics Department. An earlier version of this paper was prepared for the 2014 Bank of Korea International Conference "Strengthening Growth Potential in the Aftermath of the Global Financial Crisis”, June 2-3, 2014, Bank of Korea, Seoul, Korea. The authors thank Jonathan Ostry, Enrique Alberola, Peter Hoeller, Boris Cournede, Yvan Guillemette, Christine Lewis, Phil Bagnoli and Mark Pearson for valuable comments and discussions as well as Ines Gomez Palacio for help with documentation preparation.

2. Note that the paper here is concerned with estimating the permanent medium-term loss to the level of output once any cyclical recovery is complete. However, even if this loss turns out to be small, the cyclical loss in output (measured by a cumulative output gap) until output returns to a sustainable trend is, for many OECD countries, likely to be larger than for any other downturn experienced in the post-war period. 
- Among the 19 OECD countries which, according to Laeven and Valencia (2012), experienced a banking crisis over the period 2007-11, the median loss in potential output in 2014 is estimated to be 33/4 per cent, which is similar to OECD estimates of previous major banking crises. Among all OECD countries the median potential output loss is about 23/4 per cent in 2014.

- These effects are smaller than other widely-quoted estimates in the literature relating to the medium-term output effects of past financial crises. It is argued that this is because other studies tend to over-estimate the pre-crisis trend growth rate as a basis for the counter-factual against which output losses are evaluated.

- The estimated effects of the current crisis in this paper do, however, vary widely across countries. The most severely affected are overwhelmingly smaller European, mainly euro area, countries; the reduction in potential output in 2014 being more than 10\% for the Czech Republic, Estonia, Greece, Hungary, Iceland, Ireland and Slovenia. Conversely, for a few OECD countries, including Germany and Japan, the crisis is not estimated to have had any adverse effect on potential output.

- The largest adverse effects come from lower productivity, which is a combination of both lower total factor productivity and lower capital per worker. The decline in capital per worker accounts for more than 3 percentage points of the decline in potential output in 2014 for Estonia, Greece, Iceland, Hungary, Korea, Luxembourg and Portugal, with these countries also being among those in which the pre-crisis growth of capital per worker was most rapid.

- The contribution of lower potential employment to the crisis hit is typically much smaller than from productivity, although this contribution is more than 5 percentage points for Iceland, Ireland, Greece, Portugal, and Spain, with most of this explained by higher structural unemployment (Iceland an exception). Adverse effects on labour force participation are modest and generally much less than might have been expected on the basis of previous severe downturns, which may partly reflect pension reforms and a tightening up of early retirement pathways. Within Europe, changes in net migration flows can also explain much of the estimated effects of the crisis on movements in trend participation. Conversely, the United States is one country where there has been a marked decline in trend participation, but this is attributed mostly to demographic effects and not the effect of the crisis.

- The detail of the analysis, by country and component of potential output, confirms that there are important effects other than just the crisis, including policy effects, acting on potential output. Adjusting the estimates, to exclude such effects where they seem most obvious, suggests that the loss to aggregate OECD potential output is about 3 per cent, although there is little effect of these adjustments on the median estimates previously quoted.

- In terms of pre-crisis conditions, both higher inflation and positive output gaps (a measure of over-heating), are correlated with subsequent potential output losses. In addition, pre-crisis conditions relating to financial excesses, namely high investment, larger current account deficits, low real interest rates and high total economy indebtedness are also correlated with larger potential output losses. This provides support to arguments that macroeconomic policy should be concerned with financial developments over and above their immediate implications for inflation. Additionally, while the pre-crisis trend growth rate is not a useful predictor of subsequent output losses, faster growth in the capital-per-worker component is correlated with post-crisis potential output losses. These results therefore suggest that underlying the potential output losses was a substantial misallocation of resources, especially of capital, in the pre-crisis boom period, with rapid growth in capital contributing to unsustainable pre-crisis productivity growth. 
- More competition-friendly product market regulation is associated with smaller crisis-related losses of potential output. This suggests that more flexible product markets facilitate a reallocation of resources across firms and sectors in the aftermath of an adverse shock and so help to mitigate its consequences.

4. The remainder of the paper is organised as follows: Section 2 reviews multi-country studies which have been used to evaluate the medium-term output costs of previous financial crises; Section 3 describe the method used in the current study and presents the results of the analysis; Section 4 examines what pre-crisis macro and structural conditions and policies are correlated with the crisis hit to potential output.

\section{A selective review of recent studies of the medium-term output losses following financial crises}

5. While a number of studies have examined the immediate consequences of past financial crises, there are fewer that have focussed on the medium-term losses to output. The focus here is on 3 such studies (Cerra and Saxena, 2008; Mourougane and Furceri, 2009; and IMF, 2009), because differences between them are helpful in motivating the approach in the current paper as well as explaining differences in the results. While these studies are all relatively recent, they do not include an assessment of the effect of the current financial crisis. However, a more recent study by Ball (2014) is also considered because it does focus on the recent financial crisis and is also similar to the current paper in using OECD estimates of potential output to evaluate the medium-term output losses from the crisis.

6. The papers by Cerra and Saxena (2008) and Mourougane and Furceri (2009), hereafter referred to as CS and MF, form a natural comparison pair because both adopt a similar methodology, namely estimating an autoregressive panel model to explain GDP growth rates augmented by crisis dummies. The average effect of a crisis is then evaluated by calculating the impulse response function from the estimated coefficients. There are, however, important differences between the two papers, most notably CS consider a much broader coverage of developing and developed countries and separately distinguish the effect of banking, currency and political crises, whereas MF focus on banking and currency crises and only consider OECD countries. In order to have a better basis for comparison across the two studies and because of the greater relevance to the estimates of the effect of the current crisis, the focus here is only on a comparison of the effects of banking crises in high income countries in CS and the effect of the so-called 'Big Five' banking crises (Rheinhart and Rogoff, 2008) in MF. ${ }^{3}$ The results from the two studies are strikingly different even for what should be a similar set of crises, with the adverse effects more than $3 \frac{1}{2} 2$ times larger in CS compared to MF; thus after 10 years, CS estimate that banking crises in high-income countries reduce output by $15 \%,{ }^{4}$ whereas MF estimate a reduction of nearly $4 \%$ for the 'Big Five' crises.

7. The large difference in these estimates is probably mostly due to the different dependent variables used in each of the studies; whereas CS use actual observed GDP growth rates, MF use potential output growth rates. Using actual GDP growth rates is likely to bias upwards implicit estimates of both the pre-crisis growth rate and the pre-crisis level of GDP which is sustainable, and hence lead to an exaggerated estimate of the post-crisis loss in output. This is because prior to a financial crisis, there is typically an extended period of above average growth, usually associated with a number of symptoms of over-heating.

3. The 'Big Five’ banking crises are Spain (1977), Norway (1987), Finland (1991), Sweden (1991) and Japan (1992). Judging from the source CS use to identify banking crises, namely Caprio and Klingebiel (2003), this corresponds with the "high-income" banking crises identified by CS.

4. For upper-middle income countries, CS estimate that banking crises reduce GDP after 10 years by about $12 \%$. 
8. To illustrate the difference which using actual and potential GDP can make in establishing a counter-factual trend and hence to calculations of the medium-term output loss following a crisis, the example of OECD aggregate GDP over the recent crisis is considered. Considering the start of the crisis to be 2008 (the bankruptcy of Lehman Brothers), for the purposes of this illustration a pre-crisis OECD trend growth rate is calculated as the average growth rate over the period 2000-07 of alternatively actual or potential OECD GDP per capita (Figure 1). Alternative post-crisis counter-factuals are then calculated by extending either actual or potential OECD GDP per capita from 2007 according to their respective precrisis growth rates, where potential output estimates are taken from the latest OECD Economic Outlook projections (OECD, 2014). The counter-factual based on actual GDP per capita is progressively higher than that based on potential output; the difference in 2007 is initially 3\%, and after 10 years (the horizon used by both CS and MF) the difference is $5 \%$. This difference in the counter-factual trend is likely to translate into a corresponding difference in estimates of the medium-term output loss.

9. The approach used in IMF (2009) is to calculate medium-term output losses relative to a precrisis trend calculated using actual GDP, although it is acknowledged that estimating the pre-crisis trend is "tricky" particularly because of the problem of "insulating the analysis from the impact of any immediate pre-crisis boom or slump". The method adopted by the IMF is to estimate a linear trend through the actual GDP series during a seven year pre-crisis period that ends 3 years before the onset of the crisis. While this approach has the merit of being transparent, it will not necessarily insulate the pre-crisis trend from any immediate pre-crisis boom if there is a protracted run-up prior to the financial crisis as typically seems to be the case (Borio, 2012). For example, applying the IMF methodology to the previous example of OECD GDP over the period of the current crisis (so calculating the pre-crisis trend on actual GDP per capita over the period 1998-2005), leads to an even higher counter-factual trajectory for output (than using the trend in actual GDP per capita over 2000-7) and so an even larger medium-term output loss.

10. The use of actual GDP to establish pre-crisis trends probably explains why the IMF findings of the medium-term output loss following a financial crisis are closer to those of CS than MF and probably over-estimate the hit; for high-income countries the average reduction in GDP after 7 years is about $10 \%{ }^{5}$ Applying the IMF methodology to the current example of OECD aggregate GDP over the current financial crisis, and treating the most recent OECD projections as being realised, would give a similar result in 2015 (i.e. 7 years after the crisis) with a loss in medium-term output of just under $11 \%$. However, this estimate is likely to be an exaggeration of the permanent output loss, not only because the pre-crisis trend in output may be overstated, but also because many countries are still currently operating well below capacity. Indeed, while it might be reasonable to assume that 7 years after a typical cyclical downturn GDP has returned to its medium-term trend, following a financial crisis the downturn is likely to be more protracted (see, for example, Haugh et al., 2009).

5. For IMF (2009), the 90 per cent confidence interval around the output loss after 7 years for high-income countries is roughly between $5 \%$ and $15 \%$. The average output losses after 10 years for both low-income and middle-income countries are similar to the $10 \%$ estimate for high-income countries. 
Figure 1. OECD GDP per capita compared to various pre-crisis trends

In 2005 PPP US dollars

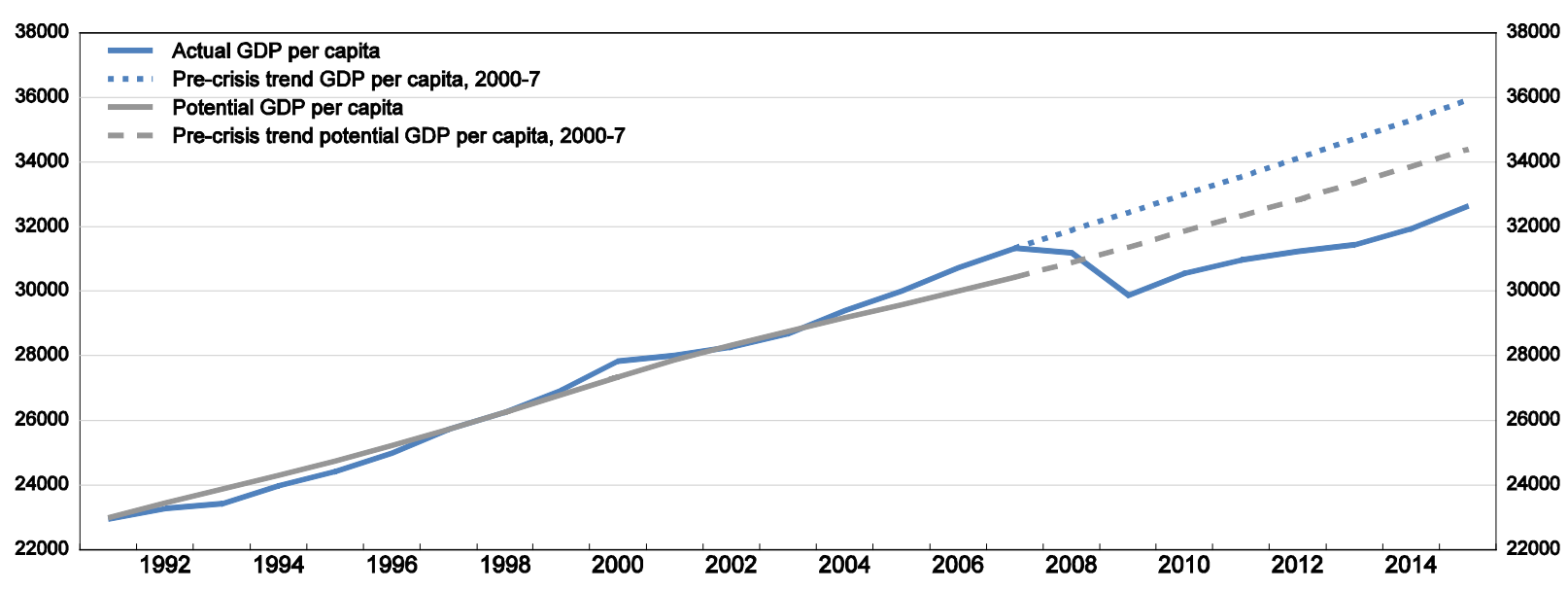

Note: OECD GDP per capita over the period 2014-15 is based on May 2014 OECD Economic Outlook projections.

Source: OECD calculations based on OECD Economic Outlook, May 2014 long-term database.

11. The justification for using potential rather than actual GDP to estimate medium-term output losses in the remainder of the paper is twofold. First because of the difficulties of establishing a pre-crisis trend and second, because GDP in many OECD countries does not appear to have returned to trend and is not expected to do so in the next year or so. ${ }^{6}$ In addition, as explained in more detail in the next section, the counter-factual used in the paper is not as crude as a simple extrapolation of the pre-crisis trend in potential output per capita (as used in Figure 1), but rather adopts different assumptions regarding different components of potential output. Using potential output does raise issues about the methodology of constructing potential output (described in Appendix 1), but these estimates do have the merit of following the same procedure across all countries and are subject to checking from country specialists.

12. In this paper, one important change which is made relative to the approach of both CS and MF, is that in common with the approach in IMF (2009), the effect of the crisis is evaluated on GDP per capita rather than just GDP. This is a simple and intuitive improvement in modelling growth given that changes in population growth are likely to imply changes in trend GDP growth of a similar order of magnitude, independently of the incidence of crises. Not taking into account such effects risks attributing the effect of a slowdown in population growth to the effect of a crisis. ${ }^{7}$

6. A further illustration of the problem of using actual GDP to generate pre-crisis trends is that it can generate estimates of large output losses even when no crisis has occurred, because strong cyclical upswings are confused with strong pre-crisis trends. For example, applying the IMF (2009) methodology to Canada, France and the United Kingdom, but treating every single year over the period 1965-2000 as a potential “crisis", gives 27 years in which output losses exceed 10\%. However, according to the various sources used by all the studies referenced in this paper, none of these countries experienced a financial crisis over this period. While a majority of these large output losses occurred in the 1970s following the first oil shock, six episodes occurred during the 1990s.

7. Moreover, changes in population growth can have quantitatively important effects on GDP growth over the medium term horizons considered in this paper. For example in the case of Japan, the difference between the annual average population growth in the decade following the 1992 banking crisis compared to the 
13. An alternative approach to estimate the crisis hit is proposed by Ball (2014) who compares recent estimates of potential output from the OECD and IMF with estimates which were made in 2007 in order to compute the damage the crisis has done to potential output (see Box 4.3 in OECD, 2010a) for a similar approach). Ball calculates an average loss, weighted by economy size, across OECD countries of $8.4 \%$. A problem, however, with comparing different vintages of potential output projections, is that both the OECD and IMF have tended to revise down estimates of both the level and growth rate of pre-crisis potential output (so pre-crisis output gaps are now more positive), implicitly recognising that there was more over-heating going on than was recognised at the time. This in turn means that the adverse effects from the crisis on potential output are likely to be exaggerated by comparing different vintages of projections. ${ }^{8}$

\section{Analysing the effect of the current crisis on potential output}

\subsection{Methodology}

14. To derive the counter-factual post-crisis trajectory for potential output per capita, the pre-crisis growth rate in trend productivity is extrapolated, but each of the components of the potential employment rate are treated differently, as explained below.

15. The current OECD method of estimating potential output, see Appendix 1 and Johansson et al, 2012 for details, assumes a Cobb-Douglas production function, which can be simplified so that potential output $\left(\mathrm{Y}^{*}\right)$ is represented in terms of potential employment $\left(\mathrm{N}^{*}\right)$, the capital stock $(\mathrm{K})$ and labouraugmenting technical progress $\left(\mathrm{E}^{*}\right)$, so that:

$$
\mathrm{y}^{*}=\alpha\left(\mathrm{n}^{*}+\mathrm{e}^{*}\right)+(1-\alpha) \mathrm{k}
$$

where lower case letters denote logs and $\alpha$ is the wage share.

16. Potential output per head of population (P) can be explained in terms of two components: trend productivity and a potential employment rate, as follows:

$$
\Delta\left(\mathrm{y}^{*}-\mathrm{p}\right)=\Delta\left(\mathrm{y}^{*}-\mathrm{n} *\right)+\Delta(\mathrm{n} *-\mathrm{p}) .
$$

17. For the purposes of the post-crisis counter-factual, the trend productivity component is extrapolated at the same average growth rate as over the pre-crisis period 2000-07. This trend productivity component can also be split into two components (each of which are assumed to follow their pre-crisis growth rate), which can be derived from combining (1) and (2), to give an effect from labour efficiency (or equivalently an effect from total factor productivity) and an effect from changes in capital per worker, represented as:

$$
\Delta\left(\mathrm{y}^{*}-\mathrm{n}^{*}\right)=\alpha \Delta \mathrm{e}^{*}+(1-\alpha) \Delta\left(\mathrm{k}-\mathrm{n}^{*}\right) .
$$

decade preceding it, was about $-0.2 \%$ per annum, which if cumulated over a decade would imply a difference in the level of GDP of $2 \%$.

8. Another problem with comparing different vintages of potential output estimates is that there are often substantial revisions to the underlying GDP data between different vintages, especially when there has been a change to the system of national accounts. Such differences are likely to be more important the further apart the vintage of projections which are compared. Ball attempts to allow for such revisions by renormalising estimates of different vintages of potential output on 2007 levels. However data revisions, especially when they involve a switch to a new system of national accounts, can also involve significant revisions to historical GDP and potential GDP growth rates. 
18. A different assumption is adopted for the potential employment component (the second term in (2)), which can itself be split into three parts:

$$
\Delta\left(\mathrm{n}^{*} \text { - } \mathrm{p}\right)=\Delta\left(\mathrm{n}^{*}-\mathrm{lf} *\right)+\Delta(\mathrm{lf} * \mathrm{pwa})+\Delta(\mathrm{pwa}-\mathrm{p}),
$$

where LF* is the trend labour force and PWA is the population of working age (here taken to be the population aged 15 to74). Each of the three right-hand-side terms is treated in a different way as follows:

- The first term on the right-hand side of (3) corresponds to the change in the structural unemployment rate. For the purposes of projecting the counter-factual, the structural unemployment rate is assumed to remain at its pre-crisis (2007) level, hence the contribution from this term to the post-crisis counter-factual growth rate is zero.

- The second term corresponds to the change in the trend labour force participation rate. One possibility would be to hold the trend labour force participation rate constant, ${ }^{9}$ however this would not allow for the effect of changes in the demographic composition of the working-age population on the aggregate participation rate. One simple way of allowing for this would be to hold age- and gender-specific participation rates constant and then project the aggregate participation rate allowing for the evolving demographic structure of the population of working age. However, a drawback of such an approach is that it does not allow for social trends whereby each generation or cohort may have a different tendency to work than its predecessors. Allowing for such effects is particularly important, for example, to capture the tendency for female participation to increase over time. Such effects are modelled here by holding the probability of entry and exit of the labour force for each age and gender cohort at its pre-crisis (2007) level. ${ }^{10}$ The evolution of the participation rate by age-gender cohort after 2007 is then influenced by what the same cohort did when younger. The counter-factual is then derived by aggregating across age-gender cohorts, although obviously it cannot take into account policy changes implemented after 2007.

- The final term captures an effect on the employment rate as the share of the working age population in total population changes. For most OECD countries, ageing populations mean that this share is declining and so acting as a drag on the employment rate. For the purpose of the post-crisis counterfactual, this term is set to its realised values and then extended with the most recent vintage of projections. The essential point is that this demographic effect is the same in the most recent estimate of potential output and in the counter-factual, so that it does not contribute to estimates of the hit from the crisis. ${ }^{11}$

19. The effect of the crisis is then evaluated as the difference between the counter-factual trend and the latest estimates and projections of potential output consistent with the projections published in the May 2014 OECD Economic Outlook. This "crisis hit" to the level of potential output can then be decomposed into an effect on trend productivity (which can be sub-divided into effects from total factor productivity and capital per worker) and potential employment (which can be sub-divided into effects from structural unemployment rate and the trend participation rate).

9. This was the approach adopted for the calculations of the effect of the crisis on potential output reported in Box 4.3 in OECD (2014a). The different approach to calculating trend labour force participation in the counter-factual explains the difference in results compared with those reported here.

10. See Annex 3 of Burniaux et al. (2004) for a more detailed explanation of this approach to projecting labour force participation.

11. Not omitting this term would risk wrongly attributing population ageing effects on the employment rate to the crisis, which in the case of some countries (including Estonia, Spain, Greece, Slovenia and Japan) and could exaggerate the crisis hit to potential by between 2 and 31/2 percentage points by 2014 . 


\subsection{Empirical results}

20. The method described above is applied to all individual OECD countries. Among the 19 countries (Austria, Belgium, Denmark, France, Germany, Greece, Hungary, Iceland, Ireland, Italy, Luxembourg, Netherlands, Portugal, Slovenia, Spain, Sweden, Switzerland, the United Kingdom and the United States) which are identified by Laeven and Valencia (2012) as having experienced a banking crisis over the period 2007-11, the median loss in potential output in 2014 is about 33/4 per cent (Figure 2(a)). Among all OECD countries, the median potential output loss is lower at about 23/4 per cent in 2014, while the loss to aggregate OECD potential output is about $2 \%$ because larger countries are estimated to have been less affected (Figure 2(b)). There is, however, wide variation in the estimated effect of the crisis on individual countries (Table 1) as summarised in the inter-quartile range (Figures 2(a)-(b)).

Figure 2. Estimated effects of the crisis on the potential output of OECD countries

Percentage reduction in potential output relative to a pre-crisis counter-factual scenario

(a) Among OECD countries experiencing a banking crisis over the period 2007-11

$\%$

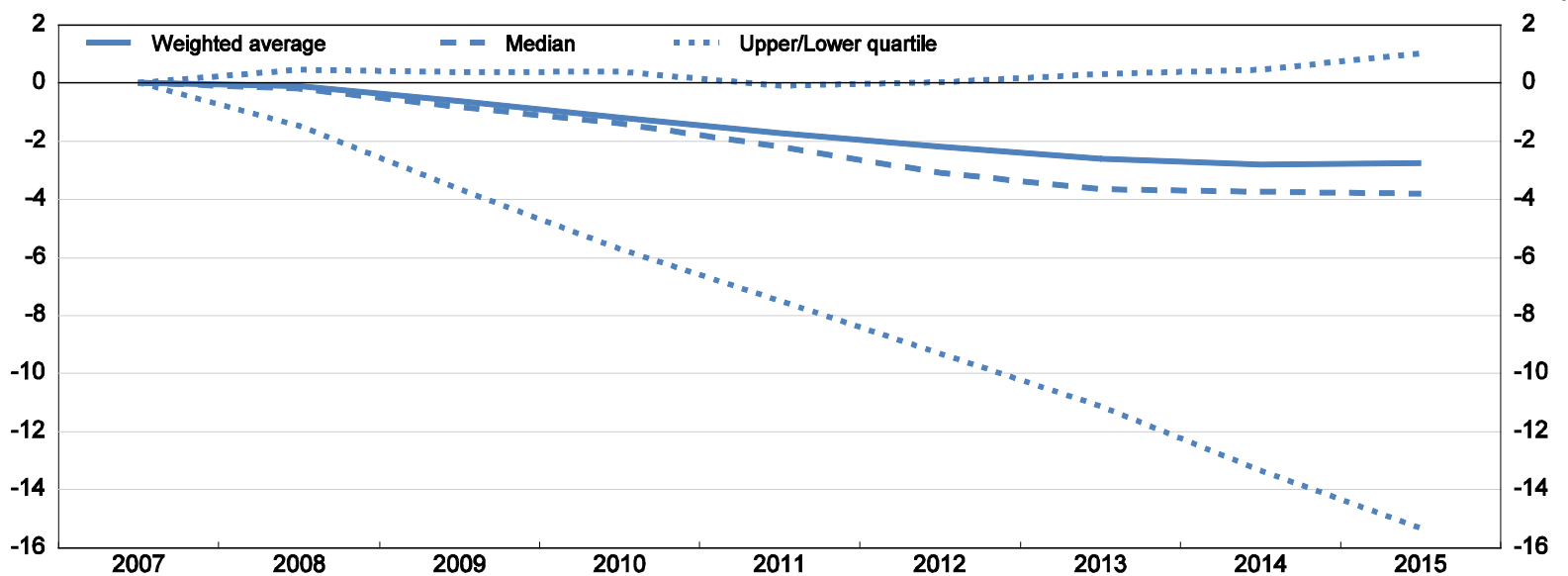

(b) Among all OECD countries

$\%$

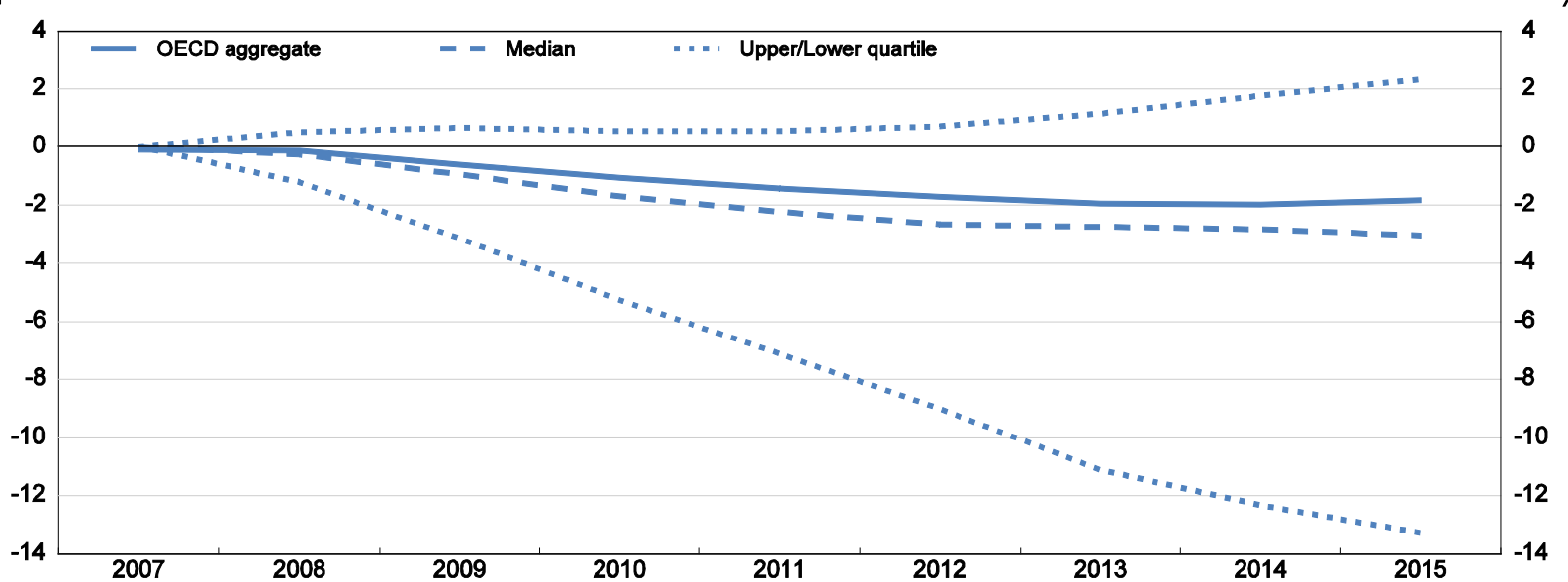

Note: Figure (a) only includes OECD countries judged to have experienced a banking crisis between 2007 and 2011 based on Laeven and Valencia (2012), whereas Figure (b) includes all OECD countries. Estimated effects of the crisis are measured relative to a counter-factual scenario in which trend productivity continues at its pre-crisis (2000-7) trend growth rate, structural unemployment rates remain at their pre-crisis (2007) levels and trend participation rates are projected to allow for evolving demographics by holding labour force entry and exit rates constant at pre-crisis levels.

Source: OECD calculations based on OECD Economic Outlook, May 2014 long-term database. 
21. The estimated impact of the crisis on individual OECD countries is heterogeneous and, especially for those most severely affected, is mostly explained by the loss in productivity (Table 1, Figure 3 and Figure 4). For the Czech Republic, Estonia, Greece, Hungary, Iceland, Ireland and Slovenia, the estimated negative impact of the crisis is above $10 \%$, mostly reflecting lower trend productivity. ${ }^{12}$ Lower productivity is both a result of lower total factor productivity and lower capital per worker, with the former typically being more important. The decline in capital per worker accounts for more than 3 per cent of the decline in potential output in 2014 for Estonia, Greece, Iceland, Hungary, Korea, Luxembourg and Portugal, with these countries also being among those in which the pre-crisis growth of capital per worker was most rapid. There are a few countries -- notably Australia, Canada and Chile -- for which the growth of capital per worker is significantly higher after the crisis than before (so boosting productivity relative to the counter-factual), but this is probably due to mining-related investment booms rather than being directly attributable to the crisis.

Table 1. Estimated effects of the crisis on the potential output of OECD countries in 2014

Percentage reduction relative to a pre-crisis counter-factual scenario

\begin{tabular}{|c|c|c|c|c|c|c|c|c|c|c|c|c|c|c|c|c|c|c|c|}
\hline & & TUR & ISR & $\mathrm{CHL}$ & DEU* & AUS & POL & FRA $^{*}$ & JPN & CAN & AUT* & NZL & OECD & $\mathrm{CHE}^{*}$ & USA $^{*}$ & BEL* & $\mathrm{NLD}^{*}$ & KOR & \\
\hline (1) & Productivity & -2.6 & 0.4 & 3.7 & -0.4 & 1.0 & -4.1 & 0.2 & -0.5 & -1.3 & -3.0 & -0.1 & -2.2 & -2.7 & -1.8 & -3.4 & -3.2 & -4.7 & \\
\hline (1a) & Capital/worker & 0.8 & 0.7 & 3.0 & -0.5 & 5.0 & 0.2 & 0.3 & -2.0 & 1.3 & -1.5 & 1.8 & -0.9 & -1.6 & -1.3 & -0.5 & 0.6 & -4.5 & \\
\hline (1b) & Total factor productivity & -3.4 & -0.3 & 0.6 & 0.1 & -3.8 & -4.3 & -0.2 & 1.5 & -2.6 & -1.5 & -2.1 & -1.3 & -1.1 & -0.5 & -2.9 & -3.8 & -1.6 & \\
\hline (2) & Employment & 10.2 & 5.1 & 0.6 & 4.3 & 1.8 & 6.2 & 0.9 & 1.4 & 0.7 & 2.1 & -1.7 & 0.2 & 0.5 & -0.7 & 0.1 & -0.2 & 1.3 & \\
\hline (2a) & Labour force participation & 10.3 & 1.6 & 0.9 & 2.9 & 2.0 & 4.8 & 1.6 & 1.6 & 0.8 & 2.0 & 0.5 & 0.8 & 0.8 & -0.3 & 0.1 & 0.0 & 1.0 & \\
\hline (2b) & Structural unemployment & -0.1 & 3.5 & -0.3 & 1.4 & -0.1 & 1.5 & -0.7 & -0.2 & -0.1 & 0.0 & -2.2 & -0.6 & -0.2 & -0.4 & 0.0 & -0.2 & 0.2 & \\
\hline (3) & Total Hit & 7.5 & 5.5 & 4.3 & 3.9 & 2.8 & 2.1 & 1.1 & 0.9 & -0.6 & -0.9 & -1.8 & -2.0 & -2.2 & -2.5 & -3.3 & -3.3 & -3.4 & \\
\hline \multicolumn{20}{|c|}{ Memorandum item: } \\
\hline & Output gap & -5.1 & 0.8 & 0.2 & 0.1 & -2.1 & -0.7 & -3.4 & 0.5 & -0.4 & -3.2 & 0.7 & -2.2 & -0.8 & -3.1 & -1.7 & -4.4 & -0.5 & \\
\hline & & NOR & ITA* & DNK* & SWE* & LUX* & MEX & SVK & FIN & ESP* & GBR $^{*}$ & PRT* $^{*}$ & CZE & IRL* & $\mathrm{SVN}^{*}$ & HUN $^{*}$ & EST & ISL* & GRC* \\
\hline (1) & Productivity & -5.3 & -2.3 & -2.6 & -5.8 & -2.4 & -7.0 & -8.9 & -8.6 & 4.4 & -9.1 & -2.4 & -12.6 & -5.4 & -9.3 & -16.5 & -13.7 & -10.1 & -13.6 \\
\hline (1a) & Capital/worker & -0.4 & -1.7 & -1.2 & -0.6 & -1.7 & -3.9 & -0.1 & 1.2 & 3.5 & -1.7 & -3.0 & -0.9 & -0.2 & -2.8 & -3.7 & -8.4 & -8.6 & -4.5 \\
\hline (1b) & Total factor productivity & -4.9 & -0.6 & -1.5 & -5.3 & -0.7 & -3.6 & -8.9 & -9.7 & 0.9 & -7.4 & 0.6 & -11.9 & -5.1 & -6.6 & -13.6 & -6.0 & -1.5 & -9.5 \\
\hline (2) & Employment & 1.4 & -1.8 & -2.1 & 1.0 & -2.6 & 1.7 & 2.3 & 1.7 & -12.4 & 0.4 & -7.3 & 2.0 & -5.6 & -4.6 & 2.1 & -1.7 & -5.8 & -9.1 \\
\hline (2a) & Labour force participation & 1.3 & 0.9 & -1.4 & 0.7 & -1.8 & 2.9 & 1.6 & 1.0 & -3.2 & 1.2 & -2.8 & 1.2 & -2.3 & -2.4 & 4.2 & -0.4 & -4.5 & -2.4 \\
\hline (2b) & Structural unemployment & 0.1 & -2.7 & -0.7 & 0.3 & -0.8 & -1.3 & 0.6 & 0.7 & -9.2 & -0.8 & -4.5 & 0.8 & -3.3 & -2.2 & -2.0 & -1.2 & -1.3 & -6.7 \\
\hline (3) & Total Hit & -3.9 & -4.1 & -4.7 & -4.8 & -5.0 & -5.4 & -6.7 & -6.9 & -8.0 & -8.6 & -9.7 & -10.6 & -11.0 & -13.9 & -14.3 & -15.4 & -15.9 & -22.7 \\
\hline \multicolumn{20}{|c|}{ Memorandum item: } \\
\hline & Output gap & -0.9 & -5.1 & -2.6 & -1.5 & -0.6 & -4.7 & -3.2 & -3.8 & -5.0 & -1.0 & -6.5 & -4.8 & -7.8 & -5.2 & -1.5 & -3.6 & -1.6 & -12.8 \\
\hline
\end{tabular}

Notes: An asterisk $(*)$ denotes that country is judged to have experienced a banking crisis between 2007 and 2011 based on Laeven and Valencia (2012). Estimated effects of the crisis are measured relative to a counter-factual scenario in which trend productivity continues at its pre-crisis (2000-7) trend growth rate, structural unemployment rates remain at their pre-crisis (2007) levels and trend participation rates are projected to allow for evolving demographics by holding labour force entry and exit rates constant at pre-crisis levels.

Row (3) = Row (1) + Row (2); Row (1) = Row (1a) + Row (1b); Row (2) = Row (2a) + Row (2b).

Source: OECD calculations based on OECD Economic Outlook, May 2014 long-term database.

12. The positive productivity effect for Spain may seem surprising, but this probably reflects the consequence of a shift of production away from construction where productivity is low. 
Figure 3. Contributions to the crisis hit on potential output for individual OECD countries

Percentage point difference in 2014 , relative to the counter-factual

$\%$

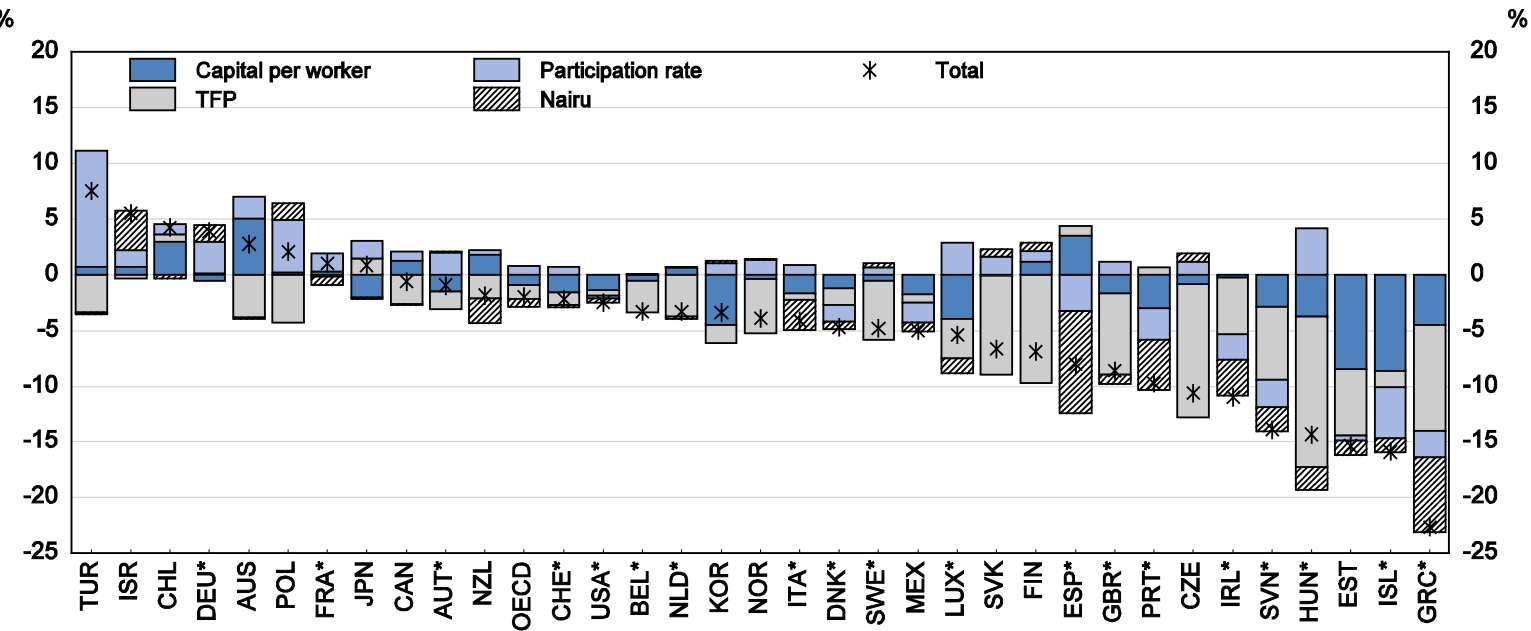

Note: An asterisk $\left(^{*}\right)$ denotes that country is judged to have experienced a banking crisis between 2007 and 2011 based on Laeven and Valencia (2012). Estimated effects of the crisis are measured relative to a counter-factual scenario in which trend productivity continues at its pre-crisis (2000-7) trend growth rate, structural unemployment rates remain at their pre-crisis (2007) levels and trend participation rates are projected to allow for evolving demographics by holding labour force entry and exit rates constant at pre-crisis levels.

Source: OECD calculations based on OECD Economic Outlook, May 2014 long-term database.

22. The contribution of lower potential employment to the crisis hit is typically much smaller, although this contribution is more than 4 percentage points for Iceland, Ireland, Greece, Portugal, Spain and Slovenia. For Greece, Portugal and Spain most of this effect is explained by a rise in structural unemployment. While the loss related to potential employment is usually less than for trend labour productivity, the adverse fiscal impact of the former may relatively more important (OECD, 2014a). There are a few countries, most notably Israel and Germany, where structural unemployment has fallen after the crisis. For Israel, the decline of the structural unemployment is partly explained by the lagged effect of policies, notably a cut in social security payments and unemployment benefits (Elkayam and Ilek, 2013). In the case of Germany, this can be attributed to the lagged effects of the Hartz reforms, which pre-dated the crisis.

23. For the majority of OECD countries, trend participation rates have held up remarkably well when assessed against the counter-factual; for the median country trend participation is marginally higher than the counter-factual (Figure 4) (which, playing by the rules of the analysis, implies a positive effect of the crisis on participation). There are some country-specific factors, particularly relating to structural reforms, which explain part of these results, as discussed further below. Nevertheless, this might be compared with the effect of previous severe downturns in OECD countries, which have been estimated to typically reduce participation rates by $1 \frac{1}{2}$ to $2 \frac{1}{2}$ percentage points over the medium term (Duval et al, 2011). The more resilient response from participation in the current crisis reflects policy reforms which increase incentives to work at older ages, including pension reforms, the phasing out of early retirement schemes and the tightening of eligibility criteria for other social transfer schemes that operated as de facto early retirement schemes (OECD, 2013). It is also possible that declines in the value of defined-contribution pensions due to falls in equity prices have encouraged workers to postpone retirement. Nevertheless, there are some countries where the decline in the participation rate has substantially contributed to the negative effect of the crisis on potential output, mostly in countries where the increase in structural unemployment has been greatest. Thus, the adverse effect of the crisis on participation is estimated to have subtracted between 2 and 41/2 percentage points from potential output in 2014 for Iceland, Ireland Greece, Slovenia and Spain. 
Figure 4. Estimated effects of the crisis on the components of potential output

Breakdown by components, deviation from the baseline

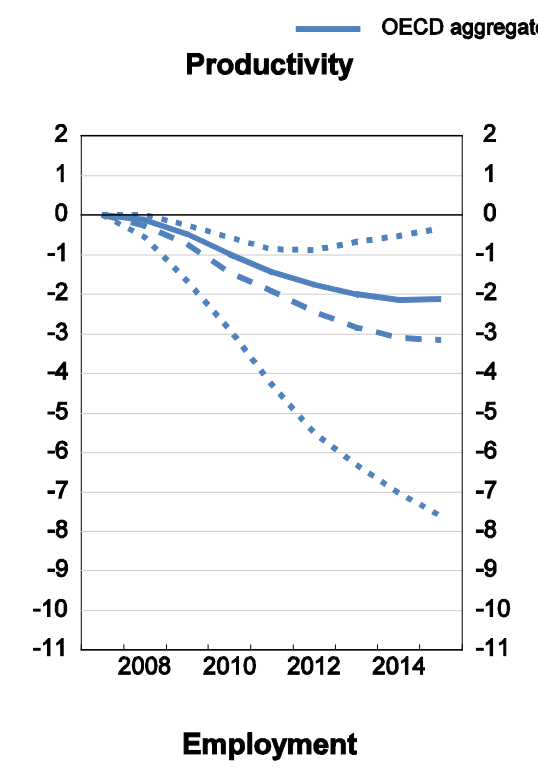

- - " Median OECD country

Capital per worker

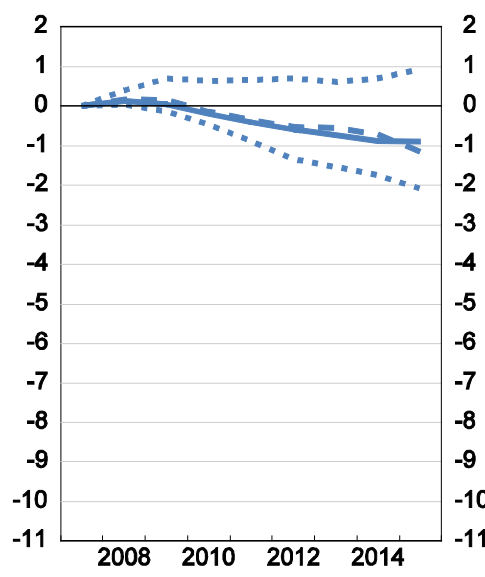

Participation

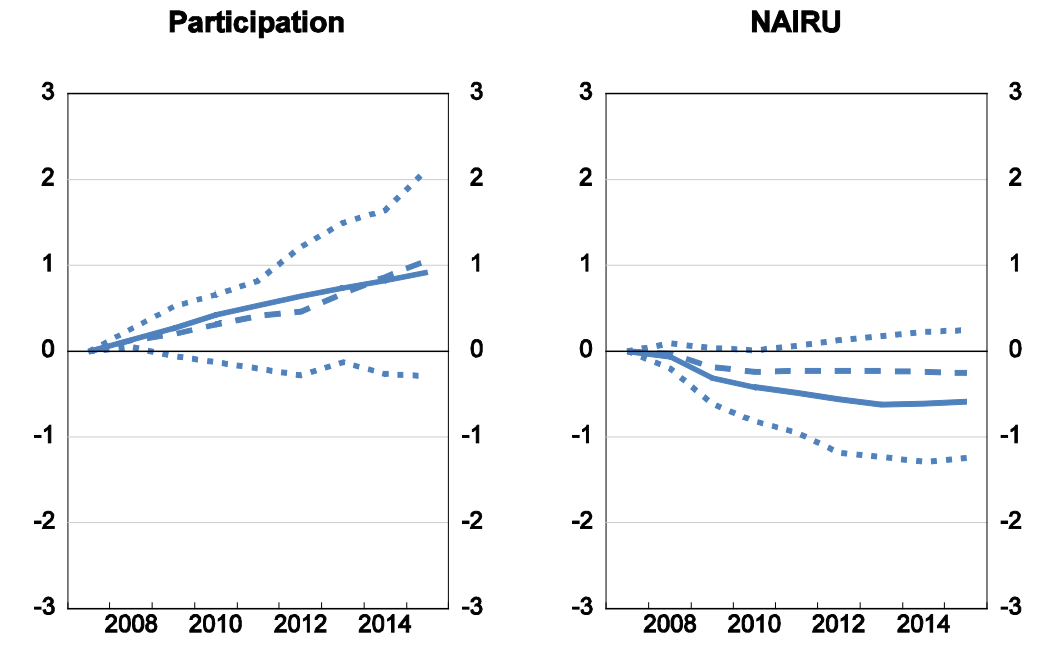

Upper/Lower quartile

TFP

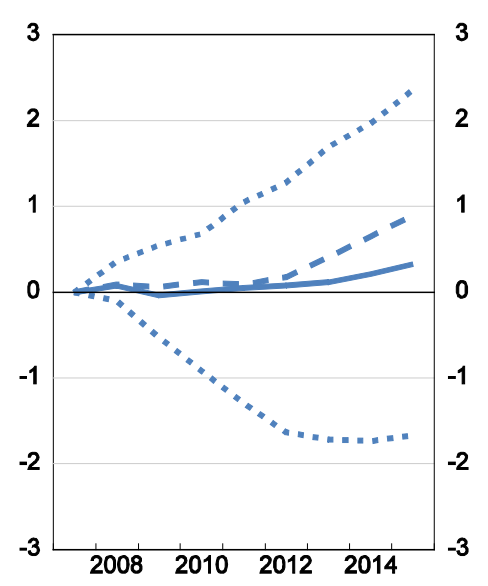

Note: Each of the components relate to their potential, i.e. cyclically-adjusted, levels.

Source: OECD calculations based on OECD Economic Outlook, May 2014 long-term database.

24. The large fall in labour force participation in the United States since the start of the crisis is worth highlighting because there has been much discussion about the extent to which this is cyclical or explained by demographic or other trend factors. ${ }^{13}$ In terms of the most recent Economic Outlook projections, the participation rate for the age group 15-74 is projected to fall by about $3 \frac{1}{2}$ percentage points between 2007 and 2014, with about 1/1/2 percentage points of this explained by cyclical factors and the remainder by a fall in the trend participation rate. In terms of the analysis presented in this paper, this fall in the trend participation rate is nearly all explained by demographic factors and so coincides closely with

13. See, for example, Erceg and Levin (2013) and Van Zandweghe (2012) for alternative views on the relative importance of demographic/trend and cyclical factors explaining the fall in US participation. 
the counter-factual and hence virtually none of the fall in the trend participation rate is attributed to the crisis. ${ }^{14}$

25. There are a number of countries -- most notably Turkey, Poland and Hungary -- for which there has been a substantial improvement in post-crisis trend participation (relative to the counter-factual) which can mostly be attributed to structural policy reforms. In the case of Turkey, a surge in participation can be attributed to the introduction of major job creation incentives in favour of disadvantaged groups (youth and women) which were very successful, particularly in a context where female participation was initially very low (OECD, 2010b). In the case of Poland, the strong rise in participation relative to the counterfactual, is mostly explained by a gradual tightening in eligibility criteria for disability benefits and for earlyretirement (OECD, 2014c). In the case of Hungary, the improvement in labour force participation rate is partly explained by new tax/benefit policies aiming to make work pay and by the stepping up of public works schemes (OECD, 2014d).

26. Another factor which helps to explain the cross-country pattern of participation effects attributed to the crisis is the evolution of net migration. For a more detailed analysis of the links between migration and the labour market situation in OECD countries, see OECD (2014e). In the aftermath of the crisis, migration flows have changed substantially, particularly inside Europe, in favour of countries in which the effect of the crisis on the labour market has been less severely affected. For example, Germany experienced a major increase in net inward migration, whereas countries like Spain or Ireland which were attracting many immigrants before the crisis are now having large net outward migration rates. Regressing the estimated effect of the crisis on the participation rate for 23 European countries (row (2a) in Table 1) with the change in net migration rate between 2007 and 2012 confirms a positive relationship which is also apparent in a simple scatter plot (Figure 5 ). ${ }^{15}$.

Figure 5. The crisis hit to participation and the change in net migration Percentage point difference

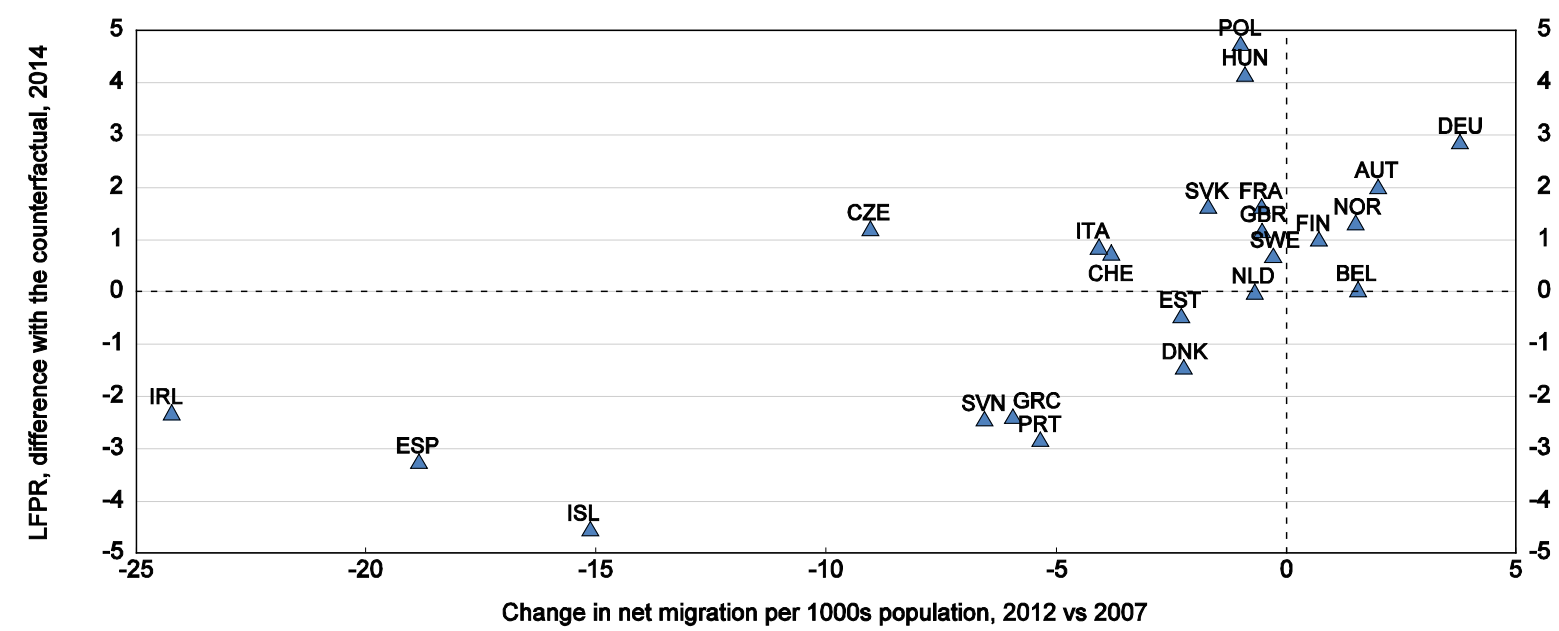

Source: OECD calculations based on OECD Economic Outlook, May 2014 long-term database.

14. If, instead, all of the fall in the trend participation rate since 2007 was attributed to the crisis then the estimated negative effect of the crisis on US potential output would rise from $2 \frac{1}{2}$ to 5 percentage points in 2014.

15. The level of the gap in participation rate for 2007 is used as a control variable and is found to be significantly negative. The R-squared of the OLS regression is about 0.6 , the coefficient on net migration (per thousand of the population) is 0.13 with a t-ratio of 2.1 . 
27. Finally, a strength of the current approach to evaluating the effect of the crisis on OECD potential output, is that results for individual countries and components of potential output are readily transparent. In some cases, this might seem to raise awkward questions, particularly when the effect of the crisis is calculated to have had a significant positive effect on some component of potential output. However, such effects serve as a reminder that while the crisis may have had a major impact on potential output, there were other effects (most notably from policy reforms) on potential output over the post-crisis period. This also raises the possibility of adjusting the estimate of the crisis hit to potential to exclude effects which can plausibly be attributed to effects other than the crisis. On this basis, an alternative adjusted estimate of the effect of the crisis on potential output can be calculated by excluding the following effects (most of which have already been mentioned in the discussion above):

- The positive effect on trend productivity due to faster post-crisis growth in capital per worker in Australia, Canada and Chile, which is probably explained by mining-related investment booms.

- Falls in structural unemployment in a number of countries -- most notably Israel, Poland and Germany -- which can be attributed to structural reforms rather than the crisis.

- The large positive effects on trend labour force participation for Turkey, Poland and Hungary which may be attributed to the effect of structural reforms.

28. Excluding these effects gives an estimate of the crisis hit to aggregate OECD potential ouput in 2014 which is revised from $2 \%$ to 3\%, although the effect on the median calculations (whether for all OECD countries or only those experiencing a banking crisis) is much smaller.

\section{Relating the crisis hit to potential output with pre-crisis conditions}

29. This section attempts to cast light on the cross-country diversity of the hit to potential output, by examining which pre-crisis conditions are correlated with it. A similar exercise was undertaken by IMF (2009) in explaining medium-term output losses from previous financial crises (but excluding the present one) and thus provides a basis for comparison. For the purpose of the current paper, the crisis hit in 2014 (row (3) in Table 1) is regressed on a range of variables summarising pre-crisis conditions relating to the macro conjuncture, indebtedness, pre-crisis trend growth and structural settings (Table 2). As the sample is relatively modest (at most 34 OECD countries), each explanatory variable was tested separately with only the addition of a control variable. The level of the output gap in 2007 is used as a control variable; it is statistically significant in nearly all cases and negatively signed, implying that those countries which were over-heating more prior to the crisis tended to be those which experienced bigger losses in potential output.

30. In terms of the pre-crisis macroeconomic conjuncture, larger current account deficits and high inflation are both correlated with larger potential output losses. High levels of pre-crisis investment or housing investment as well as low real interest rates are also correlated with potential output losses, but only if the output gap control variable is omitted. However, the pre-crisis fiscal balance is not found to be significant in explaining potential output losses. These results are broadly similar to the findings of IMF (2009), which found that high investment, large current account deficits, high inflation (relative to an historical average) all helped to explain cross-country differences in medium-term output losses from past financial crises. Overall, this provides support to arguments that macroeconomic policy should be concerned with financial developments over and above their immediate implications for inflation and fiscal balances.

31. The extent of total pre-crisis total economy indebtedness, either in terms of low net worth or high external debt, is correlated with the loss in potential output, as is more (more weakly) household net worth, but not government debt. These results confirm the findings of Sutherland and Hoeller (2013) in 
suggesting that a high level of debt creates weaknesses and vulnerabilities that both amplify shocks and limit countries scope to react during a crisis.

32. The pre-crisis trend growth rate is not a useful predictor of subsequent output losses, however faster growth in the pre-crisis capital-per-worker component is correlated with larger post-crisis potential output losses (and is the only component which is so). These results, together with those that link the scale of output losses to indebtedness and other variables associated with financial excesses, suggest that underlying the potential output losses is a substantial misallocation of resources in the pre-crisis boom, especially capital but also labour, as well as the adverse effect of debt and capital overhangs during the bust (see Borio (2013) for a discussion of typical balance sheet recessions). By the same token, the precrisis potential growth rate is likely to have been exaggerated by the boost to productivity from rapid capital accumulation, which was never likely to be sustained and so some fall in potential output relative to the pre-crisis trend was inevitable.

33. More flexible and product markets are associated with smaller crisis-related losses in potential output, which may be because this allows a more easy reallocation of resources across firms and sectors in the aftermath of an adverse shock. Thus, countries with more competition-friendly product market regulation experienced smaller losses in potential output; a difference in the OECD's PMR indicator by one standard deviation being associated with a difference in output losses of $2 \frac{1}{2} 2$ percentage points. On the other hand, while trade openness and financial openness may be related to the international transmission of shocks, only trade openness is weakly correlated with medium-term output losses. ${ }^{16}$

16. IMF (2009) has a contrary finding that greater financial openness is associated with smaller output losses, although the evidence is described as "weak" 
ECO/WKP(2014)62

Table 2. The relationship between the loss in potential output and pre-crisis conditions

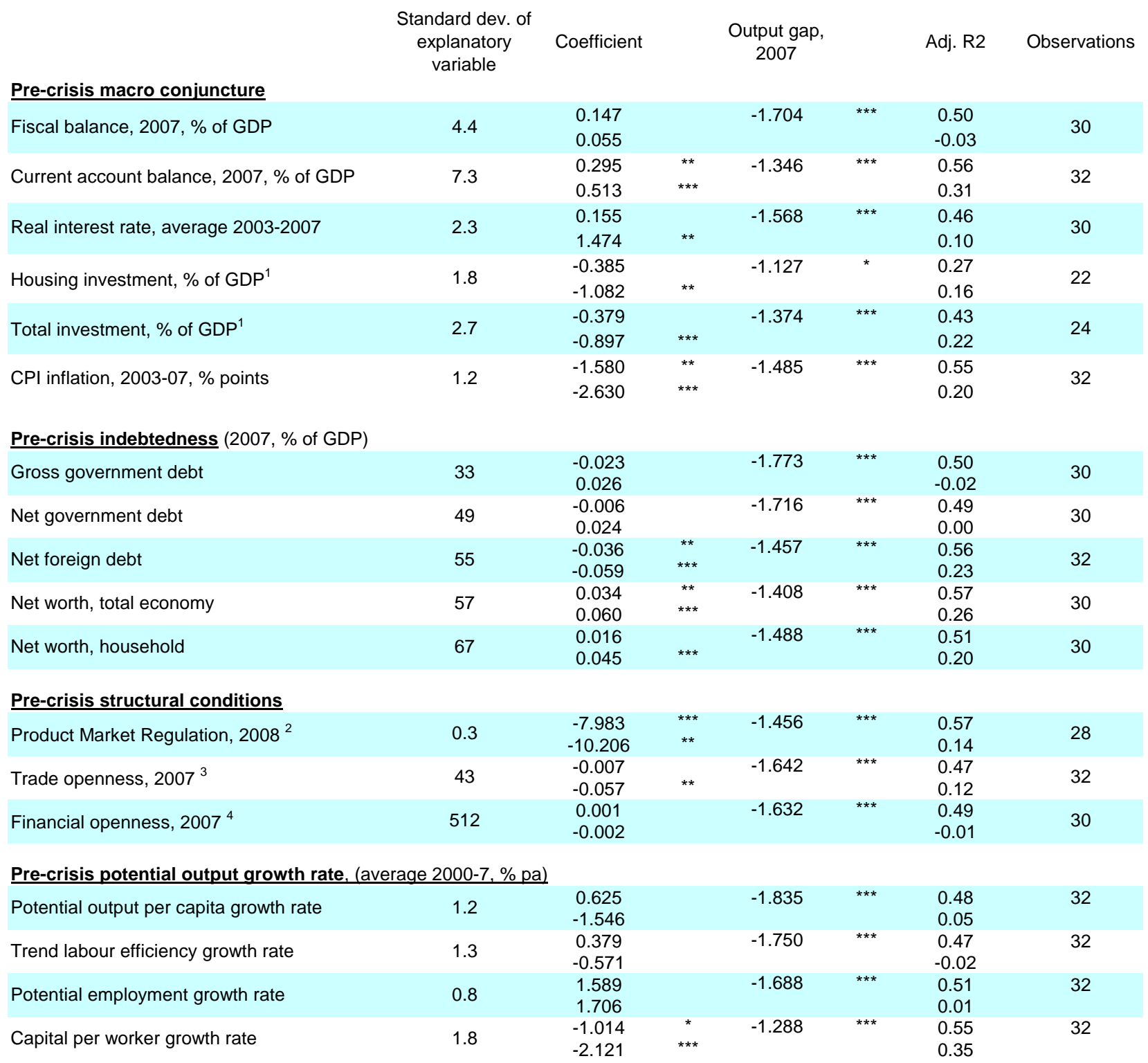

Notes: The table reports regression results where the dependent variable is the estimated percentage point effect of the crisis on potential output in 2014, taken from row (3) of Table 1, so for most countries it has a negative sign. For each of the explanatory variables, listed in the first column, two regressions are run: the first (in the upper row) also includes the pre-crisis output gap as a control variable; the second regression (in the lower row) excludes the output gap variable. Statistical significance at the 1,5 and 10 per cent level is denoted by ${ }^{\star \star *},{ }^{\star *}$, and *, respectively.

(1) Nominal housing and total investment as a percentage of GDP are measured as the difference between their averages over 200307 compared to $1980-2007$.

(2) A lower value of the Product Market Regulation indicator implies more competition-friendly regulation (see OECD (2014b) for details).

(3) Trade openness is defined as the sum in 2007 of exports and imports divided by GDP

(4) Financial openness is defined as the sum in 2007 of liabilities and assets divided by GDP.

Source: Authors' calculations based on OECD Economic Outlook, May 2014 long-term database. 


\section{APPENDIX 1. THE OECD METHODOLOGY FOR GENERATING POTENTIAL OUTPUT}

Potential output $\left(\mathrm{Y}^{*}\right)$ for the whole-economy is assumed to be determined by a Cobb-Douglas production function with constant returns to scale and factor inputs of physical capital (K), human capital $(\mathrm{H})$ and potential employment $\left(\mathrm{N}^{*}\right)$, with technical progress of the Harrod-neutral labour-augmenting form, hereafter referred to as 'trend labour efficiency' ( $\left.\mathrm{E}^{*}\right)$ :

$$
\mathrm{y}^{*}=\alpha\left(\mathrm{h}+\mathrm{n}^{*+} \mathrm{e}^{*}\right)+(1-\alpha) \mathrm{k}
$$

where lower case letters denote logarithm and $\alpha$ is the wage share.

Each component is estimated and projected separately using different techniques.

The physical capital stock is defined in terms of the non-housing productive capital stock. It corresponds to the accumulation of past non-housing investment flows, taking into account that the efficiency of assets typically falls as its life expectancy diminishes (Schreyer, 2003) and can be expressed as:

$$
\mathrm{K}_{\mathrm{t}}=\mathrm{K}_{\mathrm{t}-1}\left(1-\mathrm{r}_{\mathrm{t}}\right)+\mathrm{I}_{\mathrm{t}},
$$

where $r$ is the implicit rate of loss of productive capacity, and I is the non-housing investment flow. When available, historical data is extracted from the OECD Productivity Database. Otherwise a starting point for the capital output ratio is estimated based on average investment rate over the previous ten years and a loss rate at 4 per cent. The projected capital stock is built up from short-term projections of investment consistent with the Economic Outlook projections.

Human capital is derived from empirical estimates of the return to average years of schooling with falling marginal returns at higher level of education as in Morrison and Murtin (2010). The resulting human capital series is smoothed using an Hodrick-Prescott filter to better reflect the trend evolution of the variable.

Potential employment is computed as the combination of structural unemployment rate (NAIRU), the working-age population (PWA) and the trend participation rate (LFPR*):

$$
\mathrm{N}^{*}=L F P R^{*} \text { PWA }(1-\mathrm{NAIRU})
$$

The NAIRU is estimated using a reduced form Philips-curve by means of a Kalman filter (see Guichard and Rusticelli, 2011). Beyond the estimation period the NAIRU is usually held constant, except where there is evidence that policy reforms may have an influence or where projections imply large changes in long-term unemployment, in which case rules-of-thumb and judgement are used to revise the projection.

The working-age population is defined as the population age between 15 and 74 . The data is sourced from either Eurostat (for EU countries) or United Nations (for other countries).

The trend participation rate for the population age 15 to 74 is computed in a two-step stage. First a reduced-form equation for the actual participation rate has been estimated for each country using the unemployment gap and time trends, and the predicted values from this equation when the unemployment gap is closed are used to remove economic cycles from the actual participation rate. The resulting 
participation rate is then smoothed with a Hodrick-Prescott filter to obtain the trend participation rate. The trend participation rate is projected using a cohort model described in Johansson et al. (2012).

Labour efficiency is defined as the residual of the production function. Hence an initial (unsmoothed) estimate of labour efficiency is calculated using the Cobb-Douglas production function in (1) but using actual GDP in place of $\mathrm{Y}^{*}$ and actual employment in place of potential employment. Beyond a HodrickPrescott filter is then applied to this unsmoothed labour efficiency to provide an estimate of the trend labour efficiency. To project labour efficiency as well as to reduce end-point problems associated with using an HP-filter, data on GDP and factor-inputs is extended with short-term forecasts of these variables. Beyond a two year horizon, labour efficiency is projected using a conditional convergence model described in Johansson et al. (2012).

One simplification which is made in the main paper is to combine the human capital and trend labour efficiency component into a single component which is referred to as labour efficiency. 


\section{BIBLIOGRAPHY}

Abiad, A., R. Balakrishnan, P.K. Brooks, D. Leigh, and I. Tytell (2009), "What's the Damage? Mediumterm Output Dynamics After Banking Crises", IMF Working Paper 09/245.

Ball, L. (2014), “Long-term Damage from the Great Recession in OECD Countries”, National Bureau of Economic Research Working Paper No. 20185, May.

Borio, C., (2012), "The Financial Cycle and Macroeconomics: What Have We Learnt?", BIS Working Paper, No. 395, December.

Borio, C., (2013), "On Time, Stocks and Flows: Understanding the Global Macroeconomic Challenges", National Institute Economic Review, No. 225, August.

Burniaux, J., R. Duval and F. Jaumotte (2004), "Coping with Ageing: A Dynamic Approach to Quantify the Impact of Alternative Policy Options on Future Labour Supply in OECD Countries", OECD Economics Department Working Papers, No. 371, OECD Publishing.

Cerra, V., and S. C. Saxena. 2008. "Growth Dynamics: The Myth of Economic Recovery." American Economic Review, 98(1): 439-57.

Duval R., M. Eris and D. Furceri (2011) "The Effects of Downturns on Labour Force Participation", OECD Economics Department Working Papers, No. 875, June.

Elkayam, D. and A. Ilek (2013), "Estimating the NAIRU using both the Phillips and the Beveridge curves", Bank of Israel Discussion Paper, No. 2013.10, December.

Erceg, C., and A. T. Levin, (2013) "Labor Force Participation and Monetary Policy in the Wake of the Great Recession”, IMF Working Paper, WP/13/245, July.

Furceri, D. and A. Mourougane (2009), "The Effect of Financial Crises on Potential Output: New Empirical Evidence from OECD countries," OECD Economics Department Working Papers, No. 699.

Guichard, S. and E. Rusticelli (2011), "Reassessing the NAIRUs after the Crisis", OECD Economics Department Working Papers, No. 918, OECD Publishing.

Haugh D., P. Ollivaud and D. Turner (2009), "The Macroeconomic Consequences of Banking Crises in OECD Countries", OECD Economics Department Working Papers, No. 683.

IMF (2009), "What's the Damage? Medium-Term Output Dynamics after Financial Crises", World Economic Outlook, Chapter 4, October.

Johansson, Å.,Y. Guillemette, F. Murtin, D. Turner, G. Nicoletti, C. de la Maisonneuve, P. Bagnoli, G. Bousquet and F. Spinelli (2012), "Long Term Growth Scenarios”, OECD Economics Department Working Papers, No. 1000, February.

Laeven, L. and F. Valencia (2012), “Systemic Banking Crises Database: An Update”, IMF Working Paper, WP/12/163, June. 
Morrisson, C. and F. Murtin (2010), "The Kuznets Curve of Education: A Global Perspective on Education Inequalities", Centre for the Economics of Education Discussion Papers, No. 116, London School of Economics.

OECD (2010a). Economic Outlook, No. 87, May, OECD Publishing.

OECD (2010b). OECD Economic Surveys: Turkey, OECD Publishing.

OECD (2013), OECD Employment Outlook, OECD Publishing.

OECD (2014a), Economic Outlook, No. 95, May, OECD Publishing.

OECD (2014b), Economic Policy Reforms 2014; Going for Growth Interim Report, OECD Publishing.

OECD (2014c), OECD Economic Surveys: Poland 2014, OECD Publishing.

OECD (2014d), OECD Economic Surveys: Hungary 2014, OECD Publishing.

OECD (2014e), Matching Economic Migration with Labour Market Needs, September, OECD Publishing.

Reinhart, C. M. and K. S. Rogoff, (2009), "The Aftermath of Financial Crises", National Bureau of Economic Research. Working Paper, No. 14656, January.

Schreyer, P. (2003), "Capital stocks, capital services and multi-factor productivity measures", OECD Economic Studies, No.37, 2003/2

Sutherland D., and P. Hoeller (2012) "Debt and Macroeconomic Stability: An Overview of the Literature and Some Empirics", OECD Economics Department Working Papers, No. 1006, February.

Van Zandweghe, W., (2012), "Interpreting the Recent Decline in Labour Force Participation", FRB Kansas City Economic Review, first quarter. 


\section{WORKING PAPERS}

The full series of Economics Department Working Papers can be consulted at www.oecd.org/eco/workingpapers

1165. Determinants of households' investment in energy efficiency and renewables - evidence from the OECD Survey on household environmental behaviour and attitudes

(October 2014) by Nadia Ameli and Nicolas Brandt

1164. Addressing high household debt in Korea

(September 2014) by Randall S. Jones and Myungkyoo Kim

1163. Reducing the high rate of poverty among the elderly in Korea

(September 2014) by Randall S. Jones and Satoshi Urasawa

1162. Promoting the financing of SMEs and start-ups in Korea

(September 2014) by Randall S. Jones and Myungkyoo Kim

1161. Fostering inclusive growth by promoting structural change in the business sector.

(September 2014) by Rauf Gönenç, Oliver Röhn, Vincent Koen and Fethi Öğünç

1160. Reducing macroeconomic imbalances in Turkey

(September 2014) by Oliver Röhn, Rauf Gönenç, Vincent Koen and Evren Erdoğan Coşar

1159. Reinvigorating the EU Single Market

(September 2014) by Jean-Marc Fournier.

1158. An exploration of the determinants of the subjective well-being of Americans during the great recession

(August 2014) by Aida Caldera Sánchez and Caroline Tassot.

1157. Boosting the development of efficient SMEs in the Netherlands

(September) by Rafał Kierzenkowski and Jochebed Kastaneer

1156. Making the banking sector more resilient and reducing household debt in the Netherlands

(September 2014) by Rafał Kierzenkowski, Olena Havrylchyk and Pierre Beynet

1155. US long term interest rates and capital flows to emerging economies

(July 2014) by Eduardo Olaberria

1154. Productivity measurement with natural capital and bad outputs

(July 2014) by Nicola Brandt, Paul Schreyer and Vera Zipperer

1153. Reducing income inequality and poverty and promoting social mobility in Korea

(July 2014) by Randall S. Jones and Satoshi Urasawa

1152. Fostering a creative economy to drive Korean growth

(July 2014) by Randall S. Jones and Myungkyoo Kim

1151. Economic uncertainties and their impact on activity in Greece compared with Ireland and Portugal

(July 2014) by Jan-David Schneider and Claude Giorno 
1150. Workplace stress in the United States: issues and policies (July 2014) by Michael Darden

1149. Taxing the rent of non-renewable resource sectors: a theoretical note (July 2014) by Julien Daubanes and Saraly Andrade de Sá

1148. Health, work and working conditions: a review of the European economic literature (July 2014) by Thomas Barnay

1147. Making the best of new energy resources in the United States (July 2014) by Douglas Sutherland

1146. Improving well-being in the United States

(July 2014) by Aida Caldera Sánchez, Patrick Lenain and Sarah Fléche

1145. Deconstructing Canada's housing markets: finance, affordability and urban sprawl (July 2014) by Calista Cheung Restructurer les marchés canadiens du logement: financements, accessibilité financière et étalement urbain (Juillet 2014) par Calista Cheung

1144. Women's role in the Swiss economy (July 2014) by Richard Dutu Le rôle des femmes dans l'économie suisse (Juillet 2014) par Richard Dutu

1143. Overcoming skills shortages in Canada (July 2014) by David Carey Combler les pénuries de compétences au Canada (Juillet 2014) par David Carey

1142. Trade patterns in the 2060 world economy (July 2014) by Jean Chateau, Lionel Fontagné, Jean Fouré, Åsa Johansson and Eduardo Olaberria

1141. The Demand for Skills 1995-2008: A global chain perspective (July 2014) by Bart Los, Marcel P. Timmer and Gaaitzen J. De Vries

1140. International migration: The relationship with economic and policy factors in the home and destination country (July 2014) by Ben Westmore

1139. Gross earning inequalities in OECD countries and major non-member economies: determinants and future scenarios (July 2014) by Henrik Braconier and Jenifer Valenzuela Ruiz

1137. Managerial capital and business R\&D as enablers of productivity convergence (September 2014) Dan Andrews and Ben Westmore

1136. Long-term patterns of trade and specialisation (July 2014) by Asa Johansson and Eduardo Olaberria 